\title{
Cervical cancer, a disease of poverty: Mortality differ ences between urban and rural areas in Mexico
}

\author{
Lina Sofía Palacio-Mejía, M Sc, ${ }^{(1)}$ G udelia Rangel-Gómez, M Sc, ${ }^{(1)}$ \\ Mauricio Hernández-Avila, Dr Sc, ${ }^{(2)}$ Eduardo Lazcano-Ponce, Dr Sc. ${ }^{(2)}$
}

\begin{abstract}
Palacio-Mejía LS, Rangel-Gómez G, Hernández-Avila M, Lazcano-Ponce E. Cervical cancer, a disease of poverty: Mortality differences between urban and rural areas in Mexico. Salud Publica Mex 2003;45 suppl 3:S315-S325. This paper is available too at: http://www.insp.mx/salud/index.html
\end{abstract}

\begin{abstract}
A bstract
Objective. To examine cervical cancer mortality rates in Mexican urban and rural communities, and their association with poverty-related factors, during 1990-2000. Material and Methods:We analyzed data from national databases to obtain mortality trends and regional variations using a Poisson regression model based on location (urban-rural). Results. During 1990-2000 a total of 48761 cervical cancer (CC) deaths were reported in Mexico (1990=4 280 deaths/year; $2000=4620$ deaths/year). $0 \mathrm{n}$ average, 12 women died every 24 hours, with $0.76 \%$ yearly annual growth in CC deaths. Women living in rural areas had 3.07 higher CC mortality risks compared to women with urban residence.C omparison of state CC mortality rates (reference=Mexico $C$ ity) found higher risk in states with lower socio-economic development (Chiapas, relative risk $[R R]=10.99 ; \mathrm{N}$ ayarit, $R R=10.5$ ). Predominantly rural states had higher CC mortality rates compared to Mexico City (lowest rural population). Conclusions.CC mortality is associated with poverty-related factors, including lack of formal education, unemployment, low socioeconomic level, rural residence and insufficient access to healthcare.This indicates the need for eradication of regional
\end{abstract}

Palacio-Mejía LS, Rangel-Gómez G,

Hernández-Avila M, Lazcano-Ponce E.

Cáncer cervical, una enfermedad de la pobreza:

diferencias en la mortalidad por

áreas urbanas y rurales en México.

Salud Publica Mex 2003;45 supl 3:S315-S325.

Este artículo también está disponible en: http://www.insp.mx/salud/index.html

\section{Resumen}

Objetivo. Analizar las tasas de mortalidad por cáncer cervicouterino en las poblaciones urbanas y rurales de las regiones y entidades federativas de México, y su relación con factores relacionados con la pobreza, durante el periodo de 1990 a 2000 . Material y métodos. Se analizaron las bases de datos de población del Instituto Nacional de Estadística, Geografía e Informática, las estimaciones de población del Consejo Nacional de Población para el periodo de 1990 a 2000 y las Estadísticas Vitales de Mortalidad registradas por la Secretaría de Salud y el Instituto N acional de Estadística, G eografía e Informática. Estos datos fueron analizados para obtener tendencias de mortalidad, y se obtuvieron variaciones regionales para el mismo periodo usando un modelo de regresión de Poisson, de acuerdo con la localidad (urbanorural). Resultados. Para el periodo de 1990 a 2000 se reportaron oficialmente un total de 48761 defunciones por cáncer cérvicouterino en México, iniciado en 1990 con 4280 muertes en el año y terminado con 4620 en el 2000, lo que representa en promedio 12 mujeres fallecidas cada 24 horas, con un crecimiento promedio anual de los casos absolutos de mortalidad por cáncer cervicouterino de $0.76 \%$. Las mujeres

Acknowledgements: This article is based on the Master's thesis written by Lina Sofía Palacio Mejía, presented for her master's degree in demography at the Colegio de la Frontera N orte.The research was developed with the support of the Instituto $\mathrm{N}$ acional de Salud Pública and El Colegio de la Frontera N orte, as well as with funding from the Consorcio Transfronterizo en Salud (C ross-border Health Consortium).

(1) El Colegio de la Frontera N orte.Tijuana, Baja California, México.

(2) Centro de Investigación en Salud Poblacional, Instituto N acional de Salud Pública. Cuernavaca, Morelos, México.

Received on: January 9,2003 - Accepted on: July 29, 2003

Address reprint requests to: Dr. Eduardo César Lazcano Ponce. Director de Enfermedades Crónicas. Centro de Investigación en Salud Poblacional. Instituto N acional de Salud Pública. Avenida Universidad 655, colonia Santa María Ahuacatitlán 62508 Cuernavaca, Morelos, México. 
differences in cancer detection.This paper is available to o at: http://www.insp.mx/salud/index.html

Key words: cer vical cancer ; poverty; mortality; trends; urban; rural; Mexico que viven en el área rural tienen 3.07 veces mayor riesgo de mortalidad por este cáncer, en comparación con las mujeres residentes en el área urbana. Comparando las tasas de mortalidad por cáncer cervicouterino de las entidades federativas respecto al Distrito Federal se encontró un mayor riesgo en estados con menor desarrollo económico y social, como Chiapas, con un RR de 10.99 y N ayarit, con un RR de 10.5. Se obser vó que los riesgos de mortalidad en las entidades con mayor predominio rural aumentan considerablemente respecto al D istrito Federal, el cual posee el menor porcentaje de población rural en el país. Conclusiones. Los resultados muestran que la mortalidad por cáncer cervicouterino se encuentra relacionada con los factores presentes en la pobreza como son la falta de escolaridad, el desempleo, el bajo nivel socioeconómico, la residencia en áreas rurales y la falta de acceso efectivo a los servicios de salud. En México,este cáncer es un problema de género y equidad, por lo que debe impulsarse la eliminación de disparidades regionales en la detección de cáncer. Este artículo también está disponible en: http:// www.insp.mx/salud/index.html

Palabras clave: cáncer cervical; pobreza; mortalidad; tendencias; urbano; rural; M éxico
P overty is the lack of minimum opportunities necessary for holistic human development of individuals, due to insufficient resources and lack of effective rights to take advantage of and exploit skills or abilities. That is to say, poverty constitutes an extreme form of exclusion of individuals and their families from the productive process, social integration, and access to diverse goods, services and opportunities.

In view of this definition, and based on diverse evidence provided by a variety of studies, cervical cancer can be considered a disease of poverty. Mortality rates are higher in low socio-economic level population groups. ${ }^{1}$ High incidence rates and mortality due to cervical cancer mainly affect women living in poor countries, which frequently have deficient early detection programs for cancer. ${ }^{2}$ Cervical cancer incidence rates can be up to 15 times higher in poor countries, as compared to industrialized countries. ${ }^{3}$ Poor LatinAmerican women who have immigrated to the United States in search of work have higher cervical cancer incidence and mortality rates than white and AfroAmerican women in the US do. ${ }^{4}$

Factors such as illiteracy ${ }^{5}$ and multiparity (multiple births) ${ }^{6}$ are associated in a direct, proportional manner to cervical cancer incidence, and these factors predominate in marginalized areas in poor countries. In geographic regions with high cervical cancer inci- dence and mortality rates, there are areas of endemic human papilloma virus infection (HPV), that produces high prevalence of infection in women ${ }^{7}$ and men. ${ }^{8}$ The subtypes of HPV that are prevalent in countries with high mortality from cervical cancer (Asian, LatinAmerican and African), are probably higher risk in that they have higher oncogenic power that the European ${ }^{9}$ type.

Place of residence is a social variable, and a higher cervical cancer mortality risk in relation to residency reflects, at a great extent, health inequalities. For example, there are huge differences between urban and rural areas in terms of coverage of cervical cancer early detection programs ${ }^{10}$ and limited access to health services ${ }^{11}$ (the latter of which is the principle factor defining use of cervical cancer screening program in Mexico; $)^{12}$ to a great extent, these factors constitute an indicator of treatment opportunity. ${ }^{13}$ In sum, marginalization and poverty are two socio-economic variables that increase cervical cancer mortality risk.

Given this context, in this article we seek to explore the urban-rural differences in cervical cancer mortality rates in Mexico, a country where women are at very high risk for cervical cancer. Epidemiological data for Mexico is presented in order to evaluate the relation between cervical cancer mortality risk and type of residency and regional socio-economic development. 


\section{Material and Methods}

\section{Study design}

The correlation studies used in this article are the equivalent of geographic analysis of the determinants of mortality risk. In fact, this ecologic procedure is frequently used with population groups that are clearly defined, and represents the most straightforward approach for explaining geographic heterogeneity, while adjusting for socio-demographic variables in a multivariate model. ${ }^{14}$ The unit of analysis is therefore the group, as corresponds to an ecologic study design.

\section{Unit of observation}

The dependent variable was the cervical cancer mortality rate during the study period, and included three basic units of observation: the state (Mexico has 32 states), municipalities (administrative divisions within states) and urban-rural groupings (specific communities). Cervical cancer mortality in Mexico was analyzed for the 1990-2000 period, using official information obtained from the National Institute for Statistics, Geography and Information database (INEGI, the institute's initials in Spanish). INEGI registers reported cases of cancer with a specific reference code for cervical cancer, considered of primary origin and specific location; for the years 19901997, the reference code was cause 180 according to the $9^{\text {th }}$ International Classification of Diseases (ICD-9) and for years 1998-2000 it was cause C53 according to ICD-10.15 The denominator represents the standardized population during the study period estimated by the INEGI population and housing census and National Population Council (Conapo) estimates, in addition to preparation of population projections at the municipal level, for women of all age groups during the 1990-2000 time period.

\section{Corrections of misclassification}

Under the assumption that most cancers originally classified as unspecified tumors of the genital tract, under codes 182, ICD-9 and C54, ICD-10, were most likely cervical cancer cases, given the frequency with which they were recorded, the estimate was corrected and these were included in the numerator.

\section{Evaluation of mortality trends by age groups}

We carried out a mortality study on cervical cancer for the period covering 1990-2000, in order to evaluate cer- vical cancer mortality trends throughout the nineties and define the status of cervical cancer mortality at the beginning of the twenty-first century in Mexico. The dependent variable was cervical cancer mortality rates and the independent variable was the year of observation. In order to explain the occurrences of the event over time, a robust linear regression model was developed, under the hypothesis that beta is different from cero. Since cervical cancer mortality rates are closely related to increasing age, the rates were determined by five-year age groups.

\section{Regional analysis on cervical cancer mortality in Mexico}

For the regional analysis on cervical cancer mortality in Mexico, the years 1990, 1995 and 2000 were taken as the points of analysis, to determine the proportion of cervical cancer mortality by five-year groups in urban and rural communities from the five geographic regions and 32 states in Mexico. The Central region and the capital (Mexico City, also considered a state) were taken as reference categories, given that they have the highest socioeconomic development in the country, as well as the largest concentration of health services.

\section{Construction of the urban-rural variable}

The urban and rural variable was constructed based on a review of theory and taking into account the possibility of statistical variance in the analysis of the database information. The concept of community concentration was employed, evaluating the statistical usefulness of the size of the population in municipalities with 2 500, 5000,10000 and 15000 inhabitants (cut-off points defined by Conapo and the Ministry of Health). In this way, we created groups that would be heterogeneous in relation to each other and also internally homogeneous. These differences were observed throughout construction of cervical cancer mortality rates for 1990 to 2000, according to the different population cut-off points.

In this context, we determined that the population cut-off point that best differentiates urban and rural areas in terms of cervical cancer mortality are the municipalities with less than 2500 inhabitants. However, modern Mexico is a mainly urban country, which means the indicator would be very sensitive to changes in the annual number of cases. Therefore, for our analysis we decided to define a rural community as having less than 15000 inhabitants and urban as communities with 15000 inhabitants or more. 


\section{Evaluation of risk of cervical cancer mortality by state}

To estimate the risk of cervical cancer mortality in the states in Mexico, we constructed a Poisson multiplicative model which adjusted for age and place of residence (urban-rural), taking Mexico City's mortality rates as a reference (these rates constitute the lowest standardized mortality at the national level).

The Poisson ${ }^{16}$ probability model was used for testing a hypothesis, to evaluate the risk of cervical cancer mortality as an unusual event in a continuous space. For this model the dependent variable was the number of deaths due to cervical cancer, and the group of independent variables were: the year of observation, age group, region, state, and the urban-rural population. In order to assess the risk of mortality from cervical cancer in the female population, according to place of residence, the following equation was used.

$\log (E(y))=\beta 0+\beta$ 1year $+\beta 2$ age $+\beta 3$ region $+\beta 4$ state $+\beta 5$ urban, rural

In this way, we carried out the analysis with a sociodemographic and health approach, which allowed a more integrated view of cervical cancer mortality.

\section{Results}

\section{Cervical cancer mortality rates in Mexico, 1990-2000}

For the 1990-2000 period, a total of 48761 cervical cancer deaths were recorded nation-wide in Mexico; the yearly rate starting out in 1990 with 4280 deaths at the end of the year, and reached 4620 deaths by year 2000 . This translates into an average of 12 women dying every 24 hours from cervical cancer throughout the country, with a $0.76 \%$ yearly average increase in cases of cervical cancer mortality. If we take into account the mortality data that was probably misclassified as nonspecified uterine cancer, reclassifying these as cervical cancer cases, there are 6806 additional deaths in the study period, for a yearly average of 620 potentially misclassified deaths (Table I).

A trend towards an increase in the total female population in Mexico was observed during the study period, with a growth rate of $2.06 \%$ on average, which is higher than the increase in deaths due to cervical cancer, at $0.76 \%$. This reflects that deaths due to cervical cancer did not decrease during the study period, even though the likelihood of dying from this disease, in crude mortality rates, does show a slight decrease. This is due to the static or constant behavior of the likelihood of dying from cervical cancer, given the small decrease that can be observed in rates during an 11 year study period.

\section{Sociodemographic characteristics of women who died of cervical cancer in Mexico}

One of the socio-demographic features studied in order to try to explain the differences in mortality between urban and rural populations is the number of years of formal education that the women who died of cervical cancer had received. In this regard, $44 \%$ of women who died of cervical cancer in rural commu-

TABLE 1

Cervical cancer mortality rate in Mexico, 1990-2000

\begin{tabular}{|c|c|c|c|c|c|c|c|c|}
\hline \multirow[b]{3}{*}{ Year } & \multirow{2}{*}{\multicolumn{3}{|c|}{ Cervical cancer cases }} & \multirow[b]{3}{*}{ r*CCM G } & \multicolumn{3}{|c|}{ Total cervical cancer cases* } & \multirow{3}{*}{$\begin{array}{l}\text { r* CCM G } \\
\text { Total }\end{array}$} \\
\hline & & & & & \multirow{2}{*}{$\begin{array}{l}\text { Under wrong } \\
\text { classification }\end{array}$} & \multirow[b]{2}{*}{ Total cases } & \multirow[b]{2}{*}{ CCM R Total } & \\
\hline & Population & Cases & CCMR & & & & & \\
\hline 1990 & 40874945 & 4280 & 10.47 & & 683 & 4963 & 12.14 & 3.24 \\
\hline 1991 & 41959422 & 4194 & 10.00 & -2.03 & 611 & 4805 & 11.45 & 3.74 \\
\hline 1992 & 42869554 & 4346 & 10.14 & 3.56 & 642 & 4988 & 11.64 & 0.95 \\
\hline 1993 & 43825308 & 4369 & 9.97 & 0.53 & 572 & 4941 & 11.27 & 1.53 \\
\hline 1994 & 44829183 & 4365 & 9.74 & -0.09 & 652 & 5017 & 11.19 & 0.26 \\
\hline 1995 & 46391810 & 4392 & 9.47 & 0.62 & 612 & 5004 & 10.79 & 2.55 \\
\hline 1996 & 47184437 & 4526 & 9.59 & 3.01 & 607 & 5133 & 10.88 & 0.29 \\
\hline 1997 & 47970667 & 4534 & 9.45 & 0.18 & 614 & 5148 & 10.73 & 0.54 \\
\hline 1998 & 48739979 & 4545 & 9.32 & 0.24 & 631 & 5176 & 10.62 & 0.35 \\
\hline 1999 & 49490723 & 4590 & 9.27 & 0.99 & 604 & 5194 & 10.49 & 0.08 \\
\hline 2000 & 50224945 & 4620 & 9.20 & 0.65 & 578 & 5198 & 10.35 & \\
\hline Total & & 48761 & 9.69 & 0.76 & 6806 & 55567 & 11.05 & 0.46 \\
\hline
\end{tabular}

* Rates per 100000 women

CCMR: cervical cancer mortality rate CCMG: cervical cancer mortality growth

Source: Population forecasted by CO N APO from the XI Population and Housing General Census 1990

Vital Statistics, Mortality, IN EG I/SSA, 1990 to 2000 
nities during the year 2000, had no formal education (this surpasses the national average, which is $33.7 \%$ ), while $94 \%$ of the women had an elementary school education or less. This indicates a very low formal education level, with an average of only one year of formal education among women who died of cervical cancer in rural areas (Table II).

The formal education level of the women who died of cervical cancer in urban areas was higher than in rural areas. Among women residing in urban areas, $25 \%$ had no formal education at all, but $94 \%$ had a junior high school education or less. Comparing women who died of cervical cancer, those with urban residence had an average of three more years of formal education than those who had lived in rural areas.

The state of Oaxaca is of special interest because it has the highest proportion of women who died of cervical cancer who had no formal education at all (58.3\%), while $91 \%$ had no formal employment. This state had the highest percentage of women without social security coverage (which includes access to the social security health care system), at $65.7 \%$. These data indicate the high level of exclusion or marginalization in this state in terms of social development and women's quality life, characteristics which in turn could contribute to a growing trend in cervical cancer deaths in the future.

During the 1990-2000 period, at the time of their death due to cervical cancer, $44 \%$ of women living in rural areas and $38 \%$ of women with urban residency did not have social security coverage. In relation to this, $40 \%$ of women who lived in rural areas and died of

\section{TABLE II}

\section{SOCIODEMOGRAPHIC CHARACTERISTICS AMONG WOMEN WHO DIED OF CERVICAL CANCER IN MeXico 1990-2000}

\begin{tabular}{|c|c|c|c|c|}
\hline \multirow[b]{2}{*}{ State } & \multicolumn{2}{|c|}{$\begin{array}{l}\text { Age average at } \\
\text { the time of death }\end{array}$} & \multicolumn{2}{|c|}{$\begin{array}{l}\% \text { W ithout formal } \\
\text { schooling* }\end{array}$} \\
\hline & Rural & Urban & Rural & Urban \\
\hline Q uintana Roo & 40.2 & 59.4 & 20.00 & 29.80 \\
\hline Baja California Sur & 52.8 & 56.5 & 12.50 & 14.60 \\
\hline Colima & 55.1 & 64.3 & 14.30 & 26.80 \\
\hline Chiapas & 56.5 & 61.7 & 52.30 & 45.70 \\
\hline Sonora & 57.0 & 57.1 & 15.90 & 18.70 \\
\hline Hidalgo & 57.2 & 71.5 & 41.30 & 34.50 \\
\hline Chihuahua & 58.0 & 58.5 & 17.00 & 14.30 \\
\hline Morelos & 58.4 & 64.9 & 37.40 & 34.60 \\
\hline Coahuila & 59.0 & 60.7 & 30.20 & 16.60 \\
\hline Guanajuato & 59.4 & 65.3 & 52.40 & 41.60 \\
\hline
\end{tabular}

Source:Vital Statistics, D eath Certificates, IN EG I 1990-2000 * Illiterate cervical cancer between 1990-2000 had social security coverage provided by the Mexican Institute for Social Security (IMSS), and 6\% had coverage provided by Social Security for Public Employees (ISSSTE). In comparison, $44 \%$ of women in urban areas who died of the disease had IMSS social security coverage and $7 \%$ had ISSSTE coverage.

\section{Regional distribution of cervical cancer mortality in Mexico}

The crude rates of cervical cancer mortality showed great heterogeneity in different regions of the country. The lowest rate was found in the Central region of the country with 8.31 deaths per 100000 women and the highest rate in the South-eastern region with 11.77 deaths per 100000 women. Cervical cancer mortality rate in the North-central region were 10.13 deaths per 100000 , quite similar to the rate in the Southern region, which was 10.10 deaths per 100000 women. Finally, the Northern region was closest to the national average, with 9.41 deaths per every 100000 women during the 1990-2000 period (Figure 1).

In Mexico, the percentage of the population in each region living in communities with over 15000 inhabitants is as follows: $97 \%$ of the population in the Central region live in urban areas (thus defined), followed by $95 \%$ in the Northern region, and $93 \%$ of the population in the Southeastern region, with the lowest rates of urban residence in the Southern region at $79 \%$. The states with larger amounts of rural population are Oaxaca (22.47\%), Chiapas (28,6\%), Hidalgo (30.6\%),

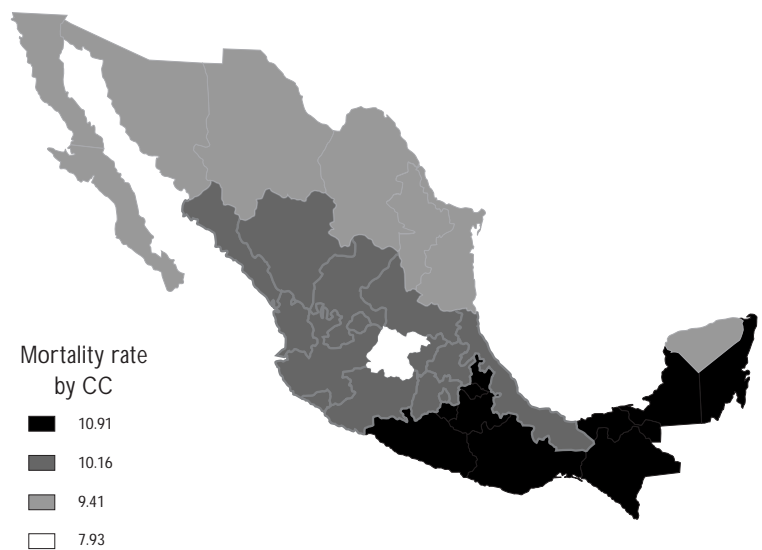

Figure 1. Cervical cancer mortality rate in Mexico, StRATIFIED BY GEOGRAPHIC REGIONS 1990-2000 
Zacatecas (33.6\%), Tabasco (34.2\%) and Guerrero (39\%). In general, states in the Northern region have a higher concentration of urban residency, while states in the Southern, Southeastern, Central and Central-northern regions have a higher concentration of rural population.

In the Central and Central-northern regions, the mortality rates in the urban and rural populations were quite similar, being only slightly higher in urban areas. In the Northern region of Mexico, the geographical area with the highest socioeconomic development after Mexico City, the cervical cancer mortality rate was higher among women living in urban areas (8.63) compared to rural (5.75), which can be explained by the high concentration of population in this region. In contrast, the Southern region, in spite of the fact that it has a medium-level population concentration, registered a higher cervical cancer mortality rate in rural areas (15.39) than in the urban zones (10.54), which could explain the increase in mortality rates that is occurring in this region.

\section{Cervical cancer mortality risk in different regions in Mexico}

The cervical cancer mortality rates by state in Mexico in the year 2000 are very heterogeneous, in that they range from lower rates of 5.71 deaths per 100000 women in the state of Zacatecas, to very high mortality rates of 16.66 deaths per 100000 women in the state of Nayarit. This implies a very high variability (10.95) between these two states, which indicates the varying distribution of the risk of dying from cervical cancer in different areas of Mexico.

In this context, the average cervical cancer mortality rate in Mexico was 9.20 deaths per 100000 women in the year 2000. The rate that remained around 9.5 during the nineties, without evidence of significant differences in mortality trends. Also, during the study period 18 states were above the national median mortality trend and 14 states were below it. Therefore, the states with the highest cervical cancer mortality rates for the year 2000 are: Nayarit with 16.66 deaths per 100000 women, Morelos with 15.44, Yucatán with 14.39, Veracruz with 11.89 and Campeche with 11.42. These states share something in common: a high percentage of women who died of cervical cancer who did not have any formal education, ranging from $31.9 \%$ in Nayarit to $42.5 \%$ in Veracruz.

Given these results, it is surprising that Mexico City, with 8.46 deaths per 100000 women, does not represent the lowest rate of cervical cancer in the country, probably due to the high concentration of health resources in this city. This could indicate an increased registry of cervical cancer deaths, given that patients with cancer are transferred to specialty hospitals for treatment and care, which for the most part are located in the capital and therefore more women tend to die of cancer in Mexico City.

Seven states showed an increase in cervical cancer mortality rates during 1990-2000, of which two are located in the Southern region. These two southern states, Chiapas and Guerrero, were also the states with the highest rate of women who died of cervical cancer who did not have a formal education $(51.7 \%$ and $50.9 \%$, respectively), as well as the highest rates of non-coverage with social security health care services $(59.5 \%$ and $47.7 \%$, respectively).

In order to evaluate cervical cancer mortality risk at a regional level, we built a Poisson regression model, taking the Central region as the comparison region, since it was found to be the region where women were at the lowest risk of dying from cervical cancer. Likewise, the 15-19 year-old age group, was taken as the comparison age group because at this age women are at the lowest risk of dying from this disease. The model had a good capacity for explanation of differences, with a pseudo $r^{2}$ of $70.44 \%$, and showed a constant, increasing cervical cancer mortality trend for the year 2000, starting at 2024 year-olds with one $(\mathrm{OR}=1.34$, with a $95 \%$ confidence interval [CI] of 1.17-1.52) up to 75 and more (OR=3.64, 95\% CI 3.49-3.79). Also, the greatest risk from dying of cervical cancer was among women over the age of 65 residing in rural areas (Figure 2).

Comparison between regions showed varying risk of death from cervical cancer in different regions, when compared with the Central region. The region with the lowest risk is the Northern region with a risk of 1.34,

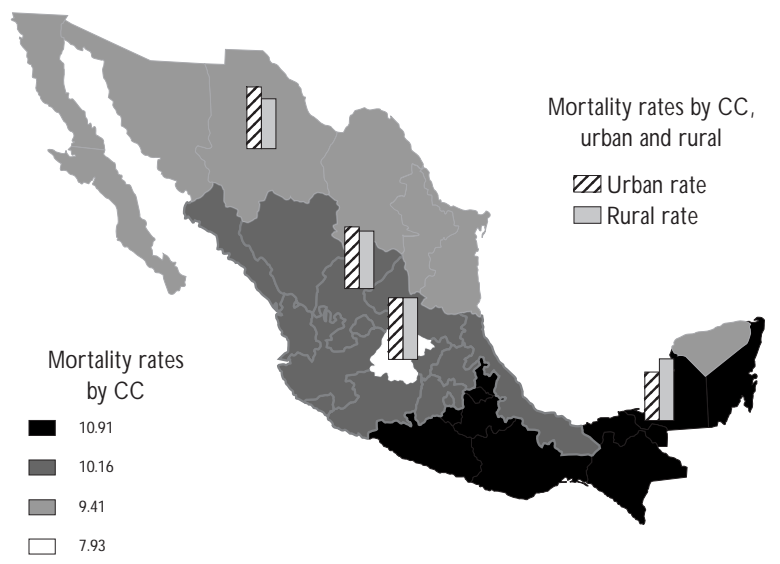

Figure 2. Cervical cancer rate in Mexico. Compared RATES URBAN VS RURAL, 1990-2000 
(95\% CI 1.22-1.49), followed by the Central-northern region with a risk of $1.56,(95 \%$ CI 1.45-1.69) while the regions with higher risks were the Southern region at 2.03 (95\% CI 1.82-2.25) and the South-eastern region at 2.04 (95\% CI 1.78-2.33), all compared to the Central region in the year 2000. In this respect, we observed higher rates of cervical cancer mortality in the states with a higher rural concentration (Figure 3).

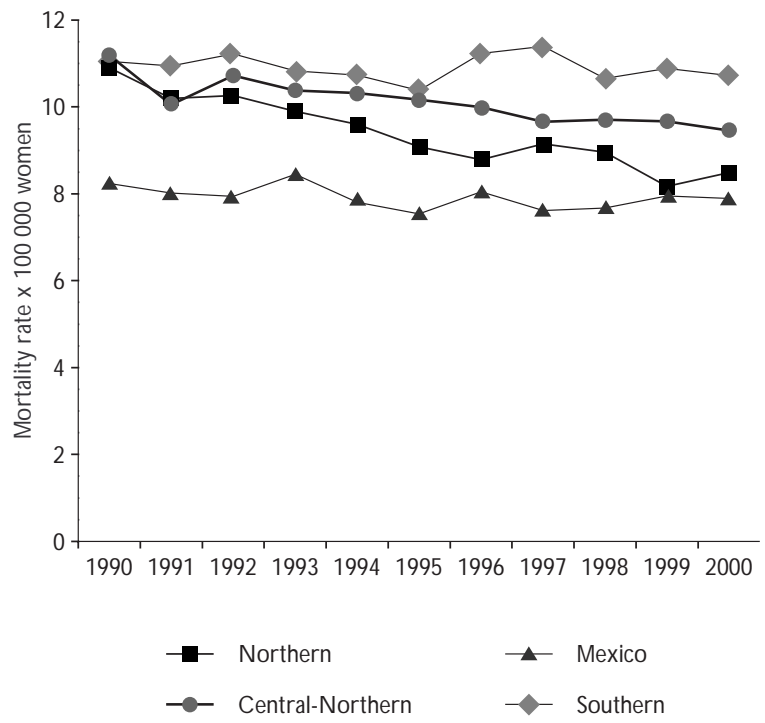

Each of the regions is integrated by the following federative entities:

1. The $\mathrm{N}$ orthern region, integrated by seven states: Baja C alifornia, Baja C alifornia Sur, Sonora, Coahuila, Chihuahua, N uevo Leon and Tamaulipas.

2. The Central-N orthern Region, the largest one, integrated by fifteen states: D urango,N ayarit, Sinaloa,A guascalientes, Colima, Jalisco, Guanajuato, Michoacán, Q uerétaro, San Luis Potosí, Zacatecas, Hidalgo, Puebla, Tlaxcala and Veracruz.

3. The Central Region, divided in two: Federal District and the State of México.

4. The Southern Region, integrated by: Morelos, Chiapas, Guerrero, 0 axaca, Campeche, $Q$ uintana Roo, Tabasco and Yucatán.

Figure 3. Cervical cancer mortality rate trends STRATIFIED IN FOUR REGIONS OF MEXICO, 1990-2000

\section{Risk of mortality from cervical cancer by state}

In order to compare cervical cancer mortality rates by state and age, we used the Poisson regression model which took Mexico City and the 15-19 year-old age group as references. This model showed that the states with the greatest relative risk are Morelos with 3.22 (95\% CI: 2.62-3.3), Chiapas with 3.16 (95\% CI: 2.67-3.74) and Nayarit with 3.14 (95\% CI: 2.46-3.99). Also, the states of Morelos, Yucatán and Nayarit were the states with the highest mortality rates for both the 1980-1990 period and the 1990-2000 period. The model showed that in the 10 states with the greatest risk of cervical cancer mortality, this risk increased over time in relation to Mexico City. It should be noted that the difference between other states and the country's capital is growing, since in the 1990-2000 period no state had a mortality risk that was lower than that of Mexico City's.

\section{Risk of mortality from cervical cancer by state, adjusted by place of residency (urban-rural)}

We developed the Poisson regression model to determine the risk of dying from cervical cancer in rural and urban areas, by state. According to this model, women who lived in a rural area had a 3.07 times greater mortality rate than women in urban areas, when comparing by state and age group. Comparing cervical cancer mortality rates between states, with Mexico City as the reference, we found the highest risk in Chiapas, where the risk was 10.99 times that of the capital city, followed by Nayarit which was 10.5 times greater (95\% CI: 4.84-23.17) and Hidalgo and Guerrero (which had a greater risk among rural population as compared to urban residency by groups of age) with a risk of 9.98 (95\% CI: 4.99-19.92) and 9.87 (95\% CI: 5.00-19.50), respectively (Table III). In states where rural residence predominated we found that mortality risks increased considerably as compared to Mexico City, which has the lowest percentage of rural population in the country.

Regarding the association between cervical cancer mortality and urban or rural residency, preliminary observation indicates that if such an association exists, it is not linear, as states that are prominently rural do not have the highest mortality rates. Likewise, the lowest mortality rates are not registered in the states with a higher percentage of urban areas, except in the state of Nuevo León. For example, the state of Zacatecas has a low percentage of urban areas and a low cervical cancer rate (5.71), while the state of Morelos has a high mortality rate (16.66) in spite of a moderate percentage of urbanization and being located in the Central region.

\section{Cervical cancer mortality trends in four geographic regions in Mexico, 1990-2000 period}

In the Northern and Central-northern regions of the country there is a clear decrease in cervical cancer mortality during the study period; although the lowest mortality rates are registered in Mexico City, this trend during the 10 year study period was stable. Meanwhile, the Southern region maintained the highest cervical 
TABLE III

Mortality RISK for Cervical CANCER in MeXico by states, 2000*

M ortality risk for cervical cancer in M exico, by states
M ortality risk for cervical cancer in M exico, by states. Adjusted by age, residence in urban and rural areas, 2000

\begin{tabular}{|c|c|c|c|c|c|c|c|}
\hline \multirow{2}{*}{$\begin{array}{c}\text { State } \\
\text { Morelos }\end{array}$} & \multirow{2}{*}{$\begin{array}{l}\text { RRM } \neq \\
3.22\end{array}$} & \multicolumn{2}{|c|}{$95 \% \mathrm{Cl}$} & \multirow{2}{*}{$\begin{array}{c}\text { State } \\
\text { Chiapas }\end{array}$} & \multirow{2}{*}{$\begin{array}{l}\text { RRM } \ddagger \\
10.99\end{array}$} & \multicolumn{2}{|c|}{$95 \% \mathrm{Cl}$} \\
\hline & & 2.63 & 3.94 & & & 5.61 & 21.53 \\
\hline Chiapas & 3.16 & 2.67 & 3.74 & $\mathrm{~N}$ ayarit & 10.59 & 4.84 & 23.17 \\
\hline $\mathrm{N}$ ayarit & 3.14 & 2.46 & 4.00 & Hidalgo & 9.98 & 5.00 & 19.93 \\
\hline Yucatán & 2.69 & 2.19 & 3.30 & Guerrero & 9.88 & 5.00 & 19.50 \\
\hline Tabasco & 2.66 & 2.11 & 3.35 & Tlaxcala & 9.55 & 4.51 & 20.20 \\
\hline Q uintana Roo & 2.51 & 1.73 & 3.64 & Q uintana Roo & 9.50 & 7.74 & 24.08 \\
\hline 0 axaca & 2.34 & 1.96 & 2.81 & Yucatán & 9.35 & 4.65 & 18.81 \\
\hline Michoacán & 2.34 & 1.98 & 2.77 & Veracruz & 9.11 & 4.77 & 17.39 \\
\hline Baja California & 2.31 & 1.87 & 2.86 & San Luis Potosí & 8.92 & 4.42 & 17.98 \\
\hline Colima & 2,29 & 1,57 & 3.34 & Morelos & 8.88 & 4.27 & 18.45 \\
\hline Guerrero & 2.18 & 1.80 & 2.63 & Puebla & 8.81 & 4.56 & 17.00 \\
\hline Campeche & 2.13 & 1.54 & 2.95 & 0 axaca & 8.65 & 4.46 & 16.79 \\
\hline Tlaxcala & 2.12 & 1.53 & 2.94 & Michoacán & 8.21 & 4.20 & 16.05 \\
\hline Jalisco & 2.10 & 1.81 & 2.43 & Colima & 7.98 & 3.03 & 20.99 \\
\hline Chihuahua & 2.04 & 1.69 & 2.47 & Zacatecas & 7.90 & 3.75 & 16.67 \\
\hline Baja C alifornia Sur & 2.04 & 1.30 & 3.20 & Durango & 7.62 & 3.60 & 16.14 \\
\hline San Luis Potosí & 2.03 & 1.65 & 2.49 & Campeche & 7.01 & 2.67 & 18.44 \\
\hline Querétaro & 2.00 & 1.50 & 2.67 & Baja C alifornia Sur & 6.79 & 2.13 & 21.66 \\
\hline Puebla & 2.00 & 1.70 & 2.35 & Tabasco & 6.44 & 2.89 & 14.34 \\
\hline Veracruz & 1.99 & 1.74 & 2.29 & Jalisco & 6.12 & 3.15 & 11.89 \\
\hline Durango & 1.81 & 1.41 & 2.34 & Querétaro & 5.27 & 2.19 & 12.67 \\
\hline Tamaulipas & 1.77 & 1.45 & 2.16 & México & 4.63 & 2.40 & 8.92 \\
\hline Coahuila & 1.75 & 1.41 & 2.17 & Guanajuato & 4.60 & 2.26 & 9.35 \\
\hline Sinaloa & 1.70 & 1.38 & 2.09 & Tamaulipas & 4.54 & 2.14 & 9.60 \\
\hline Guanajuato & 1.69 & 1.42 & 2.03 & Chihuahua & 4.50 & 2.16 & 9.39 \\
\hline Aguascalienes & 1.67 & 1.18 & 2.36 & Sonora & 4.17 & 1.90 & 9.12 \\
\hline Hidalgo & 1.50 & 1.17 & 1.92 & coahuila & 4.07 & 1.84 & 8.98 \\
\hline Sonora & 1.47 & 1.16 & 1.85 & Sinaloa & 3.65 & 1.62 & 8.22 \\
\hline México & 1.31 & 1.15 & 1.50 & N uevo León & 2.75 & 1.27 & 5.97 \\
\hline Nuevo León & 0.15 & 1.50 & 0.13 & Aguascalientes & 1.91 & 0.76 & 4.73 \\
\hline Zacatecas & 0.19 & -1.11 & 0.52 & Baja California & 0.59 & 0.18 & 1.89 \\
\hline $\begin{array}{l}\text { * Reference: Mexic } \\
\text { ‡ RRM = Relative ri }\end{array}$ & -vica & & & & & & \\
\hline
\end{tabular}

cancer rates and showed no signs of a decrease of any kind (Figure 4).

\section{Cervical cancer mortality trends in Mexico, 1980-2000 period}

Based on a previous analysis of trends in the cervical cancer mortality rate for 1980-1990 in Mexico, and comparison with the mortality rates for 1990-2000, the results of which are presented in detail here, we found that in the last 20 years in Mexico, cervical cancer mortality rates were highest between 1985 and 1995. In 1989 the highest mortality rate was recorded for the period, with 16.64 deaths per 100000 women over 15 years old. ${ }^{17}$ Rates began to decrease that year, and by the beginning of the twenty-first century had reached a rate almost equal to that recorded at the beginning of the eighties, of 12.84 deaths per 100000 women (Figure 5).

\section{Discussion}

In this study, using a multiple probabilistic model we found that in Mexico, cervical cancer mortality risk is three times higher in rural areas, as compared to urban zones, and women living in states where socio-economic development is lower have the highest mortality risks, as compared with women living in Mexico City. This indicates a huge problem in terms of unequal levels of effectiveness of the national cervical cancer prevention program, which appears to be especially problematic in the more marginalized areas.

\section{Cervical cancer: A problem linked to inequality}

A high number of cancer deaths occur in minority ethnic groups of the United States, especially among Afro- 


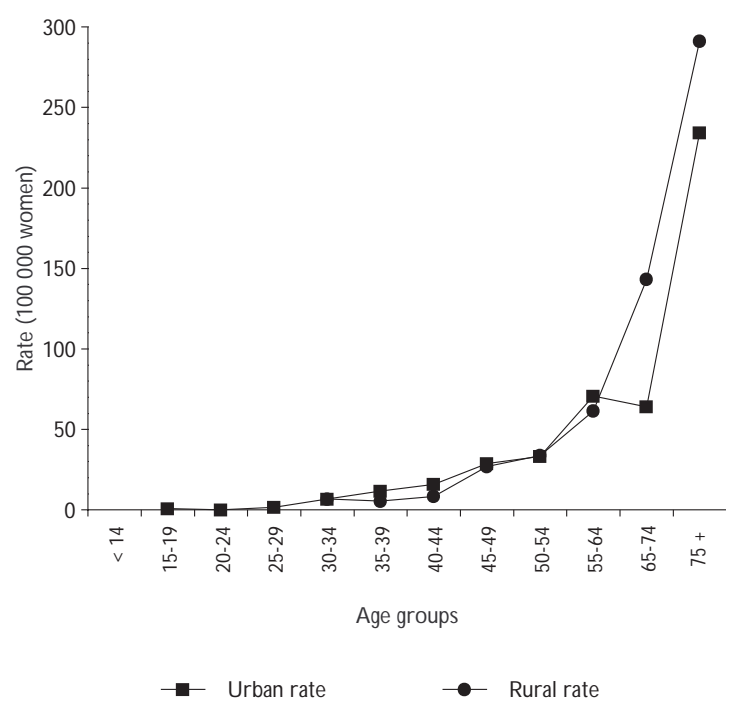

Figure 4. Cervical cancer mortality rate by age in URBan AND RURAL POPULATIONS IN MEXICO, 1990-2000

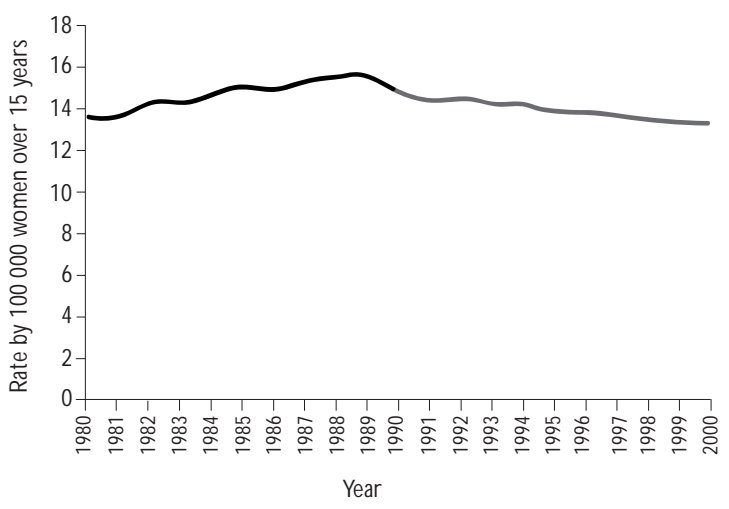

Figure 5. Cervical cancer mortality trend in Mexico, 1980-2000

American women, who have a 33\% higher risk of dying of cancer when compared to white women. ${ }^{18}$ Thus, both race and poverty have been strongly associated to high mortality due to cancer. ${ }^{19}$ This association has been attributed to poor access to medical care, not belonging to a health-care system and receiving diagnosis or treatment when the disease is in advanced stages. ${ }^{20}$ In Mexico, an estimated ten million persons do not have access to health care services, predominantly in rural areas in the southern part of the country; in addition, poverty is more prevalent in rural areas and in the south.

Poverty is a complex issue which includes elements such as unemployment and low levels of formal edu- cation. The high rates of preventable cancer found in groups living in poverty must be understood in the context of this complexity. Many factors determine socioeconomic status, and in turn these are associated with cervical cancer risk. For example, both poverty and cervical cancer risk can be associated with the huge social differences that exist between urban and rural areas in Mexico. The highest percentage of Mexican women without education or a low level of formal education is found in rural areas; this is an important socio-economic difference often linked to place of residence (urban or rural). In Mexico at the national level, nine out of ten girls from 6 to 14 years old attend school, but in rural areas only three out of every four do. Also, 30\% of women over 15 years old who live in populations of less than 2500 inhabitants are illiterate. ${ }^{21}$ Low levels of formal education in women can be related to poverty and low socio-economic level, or to gender inequality, since these low levels can be due to lack of access to education (not enough schools or leaving school in order to work) or to the belief that formal education is not a priority for girls and women.

Low levels of formal education constitute a risk factor for cervical cancer, probably because this impedes women's access to the information related to health promotion and disease prevention methods, such as early detection of cervical cancer through the Papanicolaou test and treatment when the disease is in the early stages. ${ }^{22}$ In relation to this, if a health need is not recognized, the impulse towards satisfying this need is therefore non-existent, and as a result the health care seeking process is not initiated. As a consequence, the woman in question will not use an early detection program for cervical cancer.

\section{Women living in rural areas in Mexico}

In rural areas, women's health problems are often linked to nutritional deficiencies, excessive workload and frequent pregnancies coupled with inadequate prenatal and birth care. Life expectancy in Mexican women at birth is over 3.5 years shorter in states which are more rural and have less socio-economic development (Oaxaca, Chiapas and Puebla), as compared to more urbanized northern states in Mexico (Baja California Sur and Nuevo Leon) and Mexico City. In Mexico, the infant mortality rate in rural areas is estimated at 46 per one thousand live births; this is almost $60 \%$ higher than in urban areas (even worse, in the indigenous population infant mortality reaches 56 per one thousand live births). Also, at the beginning of the nineteen-nineties, among women living in rural areas fertility was estimated at 4.7 children per woman (and 5.7 children in 
indigenous women), which is two more children than among women living in urban areas. In relation to this, a recent study reported that one of the main co-factors of cervical cancer is a history of four or more live births. ${ }^{23}$ The average age of sexual debut in rural areas is a year younger than the average age among women in urban areas (14.5 years-old in rural areas vs. 15.5 years-old in urban areas); this is a risk factor for infection of human papilloma virus, which causes cervical cancer. ${ }^{24}$

\section{Use of preventive programs in marginalized areas}

Some studies have found an association between socioeconomic level and the number of Papanicolaou tests (Pap smears, for cervical cancer detection), and have argued that this could explain certain variations in cervical cancer mortality risk among different populations. Previous reports have shown that participation in efficient detection programs is crucial to secondary prevention of cervical cancer, regardless of the frequency with which screening tests (Pap smears) are performed. If each participating woman has a lifetime history of 2-4 Papanicolaou tests, a detection program that provides at least one test every 10 years (but with total population coverage) can reduce cervical cancer incidence by between $40 \%$ and $60 \% .^{25}$

In Mexico, a previous population-based study comparing two areas, one urban and one rural, indicated there is low coverage of the early detection program for cervical cancer in marginalized areas. This study also showed that $40 \%$ of women at risk in the rural area had not had even one Papanicolaou test, while over $75 \%$ of women living in Mexico City had received one or more Pap tests. ${ }^{26}$ These results can also be observed in developed countries; for example, in France a study found low coverage of the early detection program for cervical cancer among women of low socio-economic level, lower levels of formal education, lower incomes, and with deficient use of health services. ${ }^{27}$

\section{Low-cost alternatives for early detection of cervical cancer}

Visual inspection is a low-cost technique for cervical cancer detection that has been thoroughly studied in countries with limited infrastructure for the development of an organized early detection program for cervical cancer. This strategy has been shown to have low sensitivity and specificity to detect pre-cancerous lesions of the uterine cervix. However, at present several initiatives are being undertaken in regard to this low-cost cervical cancer detection technique. For example, a trans- versal study is underway to evaluate the usefulness of visual inspection; preliminary results suggest a similar sensitivity to conventional strategies (Papanicolaou), but with a lower specificity. ${ }^{28}$ Given this finding, in regions in Mexico lacking the physical infrastructure or human resources necessary to establish an organized program, as is the case in many rural areas, the possible use of this detection strategy should be analyzed.

\section{High-cost alternatives for detection of pre-cancerous cervical lesions}

Human papilloma virus (HPV) detection could potentially be used as a test for early detection of cervical cancer, as a secondary measure for cancer prevention. ${ }^{29}$ Nevertheless, in many cases detection of the virus would occur when cancer was not yet present or was in very early stages; therefore, HPV detection would only be beneficial if used to prevent cervical cancer through early detection of asymptomatic precursor lesions. Many of HPV tests use a system that amplifies many genotypes and are based on a series of specific tests. At present, there are three systems available, including MY09/11, GP5+/6+, and hybrid capture type II. These three methods have high sensitivity and specificity for detection of oncogenic viruses and could potentially be automatized. Current technological developments have improved specificity without substantially reducing sensitivity. This could have important public health ramifications, because it has been shown that detection of HPV DNA in the absence of cytological abnormalities can indicate the presence of high grade cervical intraepithelial neoplasms (CIN), which can be overlooked (i.e., go diagnosed) when using cytology. ${ }^{30}$ The relevant studies suggest that adding an HPV test, in addition to the Papanicolaou, within a program aimed at screening for cervical cancer could increase the identification of pre-cancerous lesions of the cervix by between 50 and 100\%. Also, the existence of a self-collected vaginal specimen (the sample is collected by the woman herself, using a swab) for HPV testing means it would be possible to screen women who do not or cannot use health services provided in traditional (clinic or hospital-based) settings, as well as possibly being more acceptable to women, and therefore this option should be evaluated in rural areas (as well as other marginalized populations, especially those living in poverty). ${ }^{31}$ Future studies and prediction models are necessary to evaluate the usefulness and the cost-effectiveness of HPV test as a screening strategy and how it could be used in conjunction with other diagnosis methodologies. 


\section{Conclusions}

In conclusion, cervical cancer is a disease that is closely related to poverty and a health issue with links to gender inequality. It is also a health problem which involves regional inequalities in terms of differences in economic and social development and variability of health care infrastructure and human resources who provide primary care services. Therefore, early detection programs for cervical cancer should increasingly target both rural areas and marginalized urban sectors, given that this disease is, unfortunately, linked to poverty. If early detection efforts are efficient and effective in these areas, a large proportion of the health, social and economic impact of cervical cancer can be eliminated.

\section{References}

1. Sloggett A, Joshi H. Higher mortality in deprived areas: Community or personal disadvantage? BMJ 1994:309:1470-1474.

2. Soe MN. Screening for cervical cancer in developing countries. BMJ 1992;304:534-535.

3. Parkin M, Pisani P, Ferlay J. Estimates of the worldwide incidence of 25 major cancers in 1990. Int J C ancer 1999; 80:827-841.

4. Shavers VL, Brown M. Racial and ethnic disparities in the receipt of cancer treatment. J N atl Cancer Inst 2002;94(5):334-357.

5. D rain P, C olmes K, Highes J, Koutsky L. Determinants of cervical cancer rates in developing countries. Int J Cancer 2002;100:199-205. 6. Muñoz N , Franceschi S, Bosetti C, Moreno V, Herrero R, Smith J et al. Role of parity and human papillomavirus in cervical cancer:The IARC multicentric case-control study. Lancet 2002;359:1093-1101.

7. Bosch X, Muñoz N, De Sanjose S, Guerrero E, C haffari A M, Kaldor J et al. Importance of human papillomavirus endemicity in the incident of cervical cancer: An extension of the hypothesis on sexual behavior. Cancer Epidemiol Biomarkers Prev 1994;3:375-379.

8. Lazcano-Ponce E, Herrero R, Muñoz N, Hernández-Avila M, Salmerón J, Leyva A et al. High prevalence of human papillomavirus infection in Mexican males. Comparative study of penile-urethral swabs and urine samples. Sex Transm D is 2001;28(5):277-280.

9. Berumen J, O rdóñez RM, Lazcano-Ponce E, Salmerón J, G alván SC, Estrada RA et al.Asian A merican variants of human papillomavirus 16 and risk for cervical cancer: a case-control study. J N atl Cancer Inst 2001;93:1325-1330.

10. Lazcano-Ponce E, N ájera P, Buiatti E,Alonso P, Kuri P, Cantoral L et al. The cervical cancer screening program in Mexico. Problems with access and coverage. Cancer Causes Control 1997;8:698-704.

11. Lazcano-Ponce E, Buiatti E, N ájera P,Alonso P, H ernández M. Q uality evaluation of Mexican $\mathrm{N}$ ational Program for Early Cervical Cancer Detection and proposals for a new approach. $C$ ancer $C$ auses $C$ ontrol 1998;9;241-251.

12. Lazcano-Ponce EC, Moss S, Cruz-Valdez A, Alonso-de Ruiz P, Cáseres Q ueralt S, Martínez-León C J et al. Factores que determinan la participación en el tamizaje de cáncer cervical en el estado de Morelos. Salud Publica Mex 1999;41(4):278-285.
13. Schneider E. Measuring mortality outcomes to improve health care. Rational use of ratings and rankings. Med Care 2002;40(1):1-3. 14. Susser M.The logic in ecological: Il.The logic of design. Am J Public Health 1994:84:830-835.

15. 0 rganización Panamericana de la Salud. C lasificación Internacional de Enfermedades. Manual de clasificación y estadística internacional de enfermedades, traumatismos y causas de defunción. Revisión 1975. W ashington, D C: O PS, Volumen I, publicación científica N 0. 353. 16. Frome EL, Checkoway H. U se of Poisson regression models in estimating incidence rates and ratios. Am J Epidemiol 1985;121:309. 17. Lazcano-Ponce E, Rascón-Pacheco R, Lozano-Ascencio R,Velasco E. Mortality from carcinoma of the uterine cervix in Mexico: Impact of screening 1980-1990. Acta Cytol 1996;40(3):506-512.

18. Ries LA, Eisner MP, Kosary CL, Hankey BF, Millar BA, Clegg L et al. Ed. SEER cancer statistics review, 1973-1998. Bethesda (MD): N ational Cancer Institute, 2001.

19. Freeman H. Race, poverty and cancer. J N atl C ancer Inst 1991;83:526-527.

20. Coughlin S,ThompsonT, Seeff L, Richards T, Stallings F. Breast, cervical, and colorectal carcinoma screening in a demographically defined region of the Southern U.S. C ancer 2002;95(10):2211-2222. 21. Estados Unidos Mexicanos, Programa N acional de la Mujer 1995-2000. Alianza para la Igualdad. México, D F: Poder Ejecutivo Federal, 1-109.

22. Lazcano-Ponce EC, C astro R,Allen B, N ájera P,Alonso-de Ruiz P, Hernández-Avila M. Barriers to early detection of cervical uterine cancer in Mexico. J W omen's Health 1999;8(3):399-408.

23. Hildesheim A, Herrero R, Castle PE,W acholder S, Bratti MC, Sherman ME et al. HPV C 0 -factors related to the development of cervical cancer: Results from a population-based study in Costa Rica. Br J Cancer 2001 May 4;84(9):1219-1226.

24. Kjellberg L, Hallmans G, A hren AM, Johansson R, Bergman F, W adell $G$ et al. Smoking, diet, pregnancy and oral contraceptive use as risk factors for cervical intra-epithelial neoplasia in relation to human papillomavirus infection. Br J C ancer 2000;82:1332-1338.

25. Signan N . Socioeconomic status and cancer screening. In: Kogevinas M, Pearce N , Susser M, Boffetta P, eds. Social Inequalities in Cancer. Lyon: International A gency for Research on Cancer 1997:369-376. 26. Lazcano-Ponce EC, Moss S, Alonso-de Ruiz P, Salmerón-Castro J, Hernández-Avila M. Cervical cancer screening in developing countries: W hy is it ineffective? The case of Mexico.Arch Med Res 1999;30(3): 240-250.

27. Challier B, Meslans Y,Viel JF. D eprived areas and attendance to screening of cervix uteri cancer in a French region. $C$ ancer $C$ auses Control 2000;11:157-162.

28. Sankaranarayanan R, W esley R, Somanathan T, D hakad N, ShyamalaKumary B,A mman $S$ et al.Visual inspection of uterine cervix after the application of acetic acid in the detection of cervical carcinoma and its precursors. Cancer 1998 nov 15; 83(10):2150-2156.

29. C uzick J, Sasieni P, D avies P,A dams J, N ormand C , Frater A et al. A systematic review of the role of human papillomavirus testing within a cervical screening programme. Health Technol Assess 1999;3(14):1-204. 30. Cuzick J, Beverley E, Ho L, Terry G, Sapper H, Mielzynska I et al. HPV testing in primary screening of older women. $\mathrm{Br} \mathrm{J} \mathrm{C}$ ancer 1999;81(3):554-558.

31. D zuba IG ,Yunes-Díaz E,Allen B, Flores-Leonard Y, Lazcano-Ponce EC, Shah K et al.The acceptability of self-collected samples for HPV testing vs. the Pap test as alternatives in cervical cancer screening.J Womens Health Gen Based Med 2002;11(3):265-275. 